\title{
Efficacy of anti-tumor necrosis factor therapy for extra-articular manifestations in patients with ankylosing spondylitis: a meta-analysis
}

\author{
Dan Wu' ${ }^{1}$ Ying-Ying Guo ${ }^{2}$, Nan-Nan Xu', Shuai Zhao ${ }^{1}$, Lin-Xin Hou' ${ }^{1}$ Ting Jiao ${ }^{1}$ and Ning Zhang ${ }^{\text {** }}$
}

\begin{abstract}
Background: We performed a meta-analysis to evaluate the effect of anti-tumor necrosis factor (TNF) therapy on the frequency of extra-articular manifestations (EAMs) in patients with ankylosing spondylitis (AS).

Methods: We searched with the terms 'ankylosing spondylitis', 'infliximab', 'etanercept', 'adalimumab', 'golimumab', 'certolizumab', 'TNF inhibitor/blocker/antagonists' or 'anti-TNF' on MEDLINE, EMBASE and Cochrane Library for randomized controlled trials (RCTs) of $\geq 12$ weeks with parallel or crossover design of TNF inhibitor versus placebo to treat uveitis, inflammatory bowel disease (IBD) and/or psoriasis of AS, published before February 2014.

Results: We found 8 RCTs that fit our criteria. Anti-TNF therapy was associated with less uveitis than placebo in patients with AS (OR: $0.35,95 \% \mathrm{Cl}: 0.15-0.81, P=0.01)$. Subgroup analysis showed receptor fusion proteins were more efficacious for uveitis than placebo (OR: $0.30,95 \% \mathrm{Cl}: 0.09-0.94, P=0.04)$, but monoclonal antibodies were not (OR: $0.43,95 \% \mathrm{Cl}: 0.12-1.49, P=0.18)$. Anti-TNF therapy and placebo group did not significantly differ in treating IBD in AS patients (OR: $0.75,95 \% \mathrm{Cl}: 0.25-2.29, P=0.61$ ). In subgroup analysis, neither monoclonal antibodies (OR: $0.45,95 \% \mathrm{Cl}: 0.10-1.92, P=0.28)$ nor receptor fusion proteins (OR: $1.52,95 \% \mathrm{Cl}: 0.25-9.25, P=0.65$ ) significantly differed from placebo in treating IBD. We found no suitable reports on psoriasis.

Conclusions: Anti-TNF therapy was preventive for flares or new onset of uveitis in AS patients, and might be an alternative for these patients. However, monoclonal anti-TNF antibodies and TNF receptor fusion proteins were not efficacious for IBD in AS patients.
\end{abstract}

Keywords: Ankylosing spondylitis, Anti-TNF therapy, Extra-articular manifestations, Uveitis, Inflammatory bowel disease, Meta-analysis

\section{Background}

Ankylosing spondylitis (AS) is a chronic, progressive, inflammatory rheumatic disease that primarily affects the sacroiliac joints [1]. AS is primarily a disease of the axial skeleton, but some patients have peripheral joint involvement [2]. AS also has some extra-articular manifestations (EAMs). An epidemiological study in Belgium found that $42 \%$ of patients with definite AS had one or more EAMs [3]. EAMs mostly occurred in the eye (uveitis), gastrointestinal tract (inflammatory bowel disease, IBD) and skin (psoriasis) [4].

\footnotetext{
*Correspondence: zhangn_sjhospital@163.com

'Second Departments of Rheumatology, Shengjing Hospital of China Medical University, 39, Huaxiang Road, Tiexi District, Shenyang 110022, Liaoning, China

Full list of author information is available at the end of the article
}

Uveitis, which is characterized by pain with red eye and photophobia, increased tear production and blurring of vision [5], occurs in approximately $20-30 \%$ of AS patients during the course of their disease, and is considered the most common EAM [6,7]. Non-steroidal anti-inflammatory drugs (NSAIDs) can only relieve uveitis symptoms for a short period in AS patients, but cannot change the course of their disease or prevent structural damage. NSAIDs treatment can also increase the tendency towards osteoporosis if used for a longer period of time. Some evidence indicates that diseasemodifying anti-rheumatic drugs (DMARDs) can reduce uveitis recurrence $[8,9]$. TNF is present at high concentrations in both aqueous humor and serum of patients with uveitis [10], and may participate actively in the 
pathogenesis of uveitis. In recent years, several trials have demonstrated the efficacy of anti-TNF therapy in reducing acute uveitis $[11,12]$.

IBD is characterized by a chronic inflammation of the gut mucosa and includes Crohn's disease (CD) and ulcerative colitis (UC). A recent systematic review and metaanalysis showed the pooled prevalence of IBD in patients with AS to be 6.8\% [7]. Traditionally, treatment of IBD has relied on corticosteroids to reduce flares and on immunomodulators to maintain remission [13]. Aminosalicylic acid is widely used to treat $\mathrm{UC}$, but its use in CD is controversial [14]. Several recent trials have demonstrated the efficacy of anti-TNF therapy in reducing IBD [15].

Psoriasis is a systemic inflammatory cutaneous disease with plaque lesions and nail deformities. The pooled prevalence of psoriasis, a secondary disorder in AS, was 9.3\% in patients with AS [7].

In a 2010 update by the Assessments in Ankylosing Spondylitis International Society and the European League against Rheumatism (ASAS/EULAR) of recommendations for the management of AS [16], NSAIDs are considered the first-line drug treatment for AS patients with pain and stiffness; DMARDs and intra-articular injections of glucocorticoids in patients with peripheral arthritis may also be considered, although there is no evidence to support the use of these medications for axial diseases; anti-TNF therapy is another option for patients with persistently high disease activity despite conventional treatments.

Infliximab (INF) is a chimeric mouse-human monoclonal immunoglobulin G (IgG) 1 antibody [17]. Adalimumab (ADA) [18], golimumab (GOL) [18] and certolizumab (CZP) [19] are humanized monoclonal anti-TNF- $\alpha$ antibodies. Etanercept (ETA) [20] is a dimeric fusion protein of the TNF receptor linked to the Fc portion of human IgG1.

Additionally, trials of anti-TNF therapy in AS have yielded impressive results [21-25] and a recent systematic review and meta-analysis [26] described the benefits of anti-TNF therapy in patients with AS. However, only a small trial has reported on the efficacy of anti-TNF therapy for EAMs of AS [11], and further meta-analysis could strengthen this evidence. Therefore, we performed a metaanalysis of randomized clinical trials (RCTs) to provide an up-to-date and comprehensive picture of the clinical efficacy of anti-TNF therapy for the most common EAMs in patients with AS-uveitis, IBD and psoriasis.

\section{Methods}

We captured all relevant studies published before February 2014 on MEDLINE, EMBASE and the Cochrane Library using following search terms: 'ankylosing spondylitis', 'infliximab', 'etanercept', 'adalimumab', 'golimumab', 'certolizumab', 'TNF inhibitor/blocker/antagonists' or 'anti-TNF'.
Studies included in this meta-analysis met the following criteria: they were RCTs; their duration of study was $\geq 12$ weeks; they used a parallel or crossover design of TNF inhibitor versus placebo treatment; and their data included information on uveitis, IBD and psoriasis in patients with AS.

Two independent investigators determined the relevance of the cited articles by reading the abstracts. Disagreements were resolved through discussion and consensus or, as needed, with consensus with a third investigator. When there were multiple articles from the same trial, the most complete and recently reported data were included.

Evaluations of methodological quality and risk of bias were performed independently by two reviewers, and disagreements between the two were resolved by consensus. Methodological quality of included articles was further assessed using modified Jadad criteria with an 8-item scale designed to assess randomization, blinding, withdrawals and dropouts, inclusion and exclusion criteria, adverse effects and statistical analysis [27]. Score range was from 0 (lowest quality) to 8 (highest quality). Scores of 4-8 denoted good to excellent (high quality) and 0-3 poor or low quality. Risk of bias was assessed according to the recommendations of the Cochrane Collaboration, classified as having either a low, high or unclear risk of bias $[28,29]$. Assessment of risk of bias in the included studies was based on sequence generation, allocation concealment, blinding (of participants, personnel and outcome assessors), incomplete outcome data, selective outcome reporting and other sources of bias, such as baseline imbalance and early stopping bias.

The statistical analysis was performed using Review Manager 5.2 (The Nordic Cochrane Centre, Copenhagen, Denmark) from the Cochrane Collaboration, 2013. Categorical dichotomous variables were assessed using the odds ratio (OR). $P<0.05$ was considered to be statistically significant; 95\% confidence intervals $(\mathrm{CI})$ were reported. Homogeneity was tested using the Q statistic (significance level at $P<0.10$ ) and the $I^{2}$ statistic (significance level at $I^{2}>50 \%$ ) [30]. A random-effects model was used if the Q or $I^{2}$ statistic was significant. Otherwise, a fixed-effects model was used. The existence of a publication bias for the meta-analysis was examined using a funnel plot. To assess the potential confounding effect of heterogeneity, subgroup analyses were performed. According to TNFinhibitor classification, we divided those into two subgroups of TNF receptor fusion proteins (ETA) and monoclonal anti-TNF antibodies (INF, AND, GOL and CZP).

\section{Results}

A total of 1,395 relevant articles were retrieved from various databases of which 801 were excluded after scanning 
the titles; 521 after carefully reading the abstracts; and an additional 65 articles for various reasons (duplicates, not RCT or no required data; Figure 1). Finally, 8 RCTs were retained for meta-analysis [31-38]. Overall, included studies were of adequate methodological quality (mean modified Jadad score 6.875 for included studies, and all 8 studies had a score $\geq 6$ ). Included studies, basic characteristics of enrolled patients and details about drug therapy are presented in Table 1.

The pooled analysis included 1,770 patients $(1,223$ randomized to anti-TNF therapy and 547 to placebo). Six trials [32-36,38] reported on uveitis that occurred in 7 patients in the anti-TNF therapy group and 16 in the placebo group; 5 trials $[31,33,34,37,38]$ reported on IBD that occurred in 5 patients in the anti-TNF therapy group and 4 in the placebo group. No included trial reported on psoriasis.

Anti-TNF therapy was associated with less uveitis than placebo in patients with AS (OR: 0.35, 95\% CI: 0.15$0.81, P=0.01$, Figure 2). Subgroup analysis for uveitis in patients with AS showed TNF receptor fusion proteins to be more efficacious than placebo (OR: $0.30,95 \% \mathrm{CI}$ : 0.09-0.94, $P=0.04$ ); whereas monoclonal anti-TNF antibodies did not significant differ from placebo (OR: 0.43, 95\% CI: $0.12-1.49, P=0.18)$. Analysis for IBD in these patients found that the anti-TNF therapy and placebo did not significantly differ (OR: $0.75,95 \%$ CI: 0.25-0.29, $P=0.61$, Figure 3); and neither monoclonal anti-TNF antibodies (OR: 0.45 , 95\% CI: $0.10-1.92, P=0.28$ versus placebo) or receptor fusion proteins (OR: 1.52, 95\% CI: $0.25-9.25, P=0.65$ versus placebo) significantly differed from placebo. Funnel plot analysis showed symmetry, which indicates that publication bias was not a significant factor in these studies (Figures 4 and 5).

Analysis of risk of bias showed that only 3 trials reported their methods of sequence generation and allocation concealment in detail [32,35,36]. Blinding was performed properly in all included trials. All trials were free from incomplete outcome data and free from selective outcome reporting as well as other sources of bias. All 8 included trials had low or moderate risk of bias (Table 1).

\section{Discussion}

This meta-analysis compared anti-TNF therapy with placebo in patients with AS. The results indicate significant positive benefits of anti-TNF agents to treat uveitis in these patients. For IBD treatment outcomes, the antiTNF therapy group and the placebo group did not significantly differ. However, Subgroup analysis showed the receptor fusion protein ETA was more efficacious than placebo for uveitis in this patient population, whereas

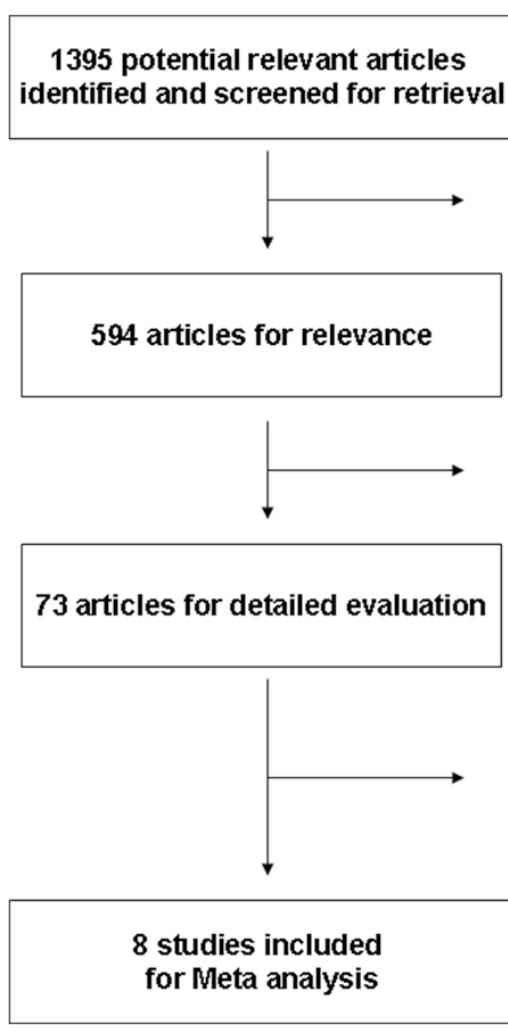

801 articles excluded after scanning the titles

521 articles excluded based on review of abstract

65 articles excluded due to one

of the following reason

1. Duplicate

2. Not RCT

3. No required data

Figure 1 Flow chart demonstrating the process of study selection. 
Table 1 Basic characteristics of included studies

\begin{tabular}{|c|c|c|c|c|c|c|c|c|c|c|c|c|c|}
\hline \multirow[t]{2}{*}{ Study } & \multirow{2}{*}{$\begin{array}{l}\text { No. of } \\
\text { patients }\end{array}$} & \multirow{2}{*}{$\begin{array}{l}\text { Age } \\
\text { (years) }\end{array}$} & \multirow{2}{*}{$\begin{array}{l}\text { Male } \\
\text { patients } \\
\mathrm{N}(\%)\end{array}$} & \multirow{2}{*}{$\begin{array}{l}\text { Duration of } \\
\text { AS (years) }\end{array}$} & \multirow{2}{*}{$\begin{array}{l}\text { Study } \\
\text { Duration } \\
\text { (weeks) }\end{array}$} & \multirow{2}{*}{$\begin{array}{l}\text { Medications allowed } \\
\text { during the study }\end{array}$} & \multirow{2}{*}{$\begin{array}{l}\text { Modified } \\
\text { Jadad } \\
\text { Score }\end{array}$} & \multicolumn{6}{|l|}{ Risk of bias } \\
\hline & & & & & & & & $\begin{array}{l}\text { Sequence } \\
\text { generation }\end{array}$ & $\begin{array}{l}\text { Allocation } \\
\text { concealment }\end{array}$ & blinding & $\begin{array}{l}\text { Incomplete } \\
\text { outcome } \\
\text { data }\end{array}$ & $\begin{array}{l}\text { Selective } \\
\text { outcome } \\
\text { reporting }\end{array}$ & $\begin{array}{l}\text { other } \\
\text { sources } \\
\text { of bias }\end{array}$ \\
\hline \multicolumn{14}{|l|}{$\overline{A D A}$} \\
\hline $\begin{array}{l}\text { van der Heijde D. } \\
2006[31]\end{array}$ & 315 & & & & 24 & $\begin{array}{l}\text { DMARDs, NSAIDs and } \\
\text { glucocorticoids }\end{array}$ & 6 & $?$ & $?$ & $\sqrt{ }$ & $\sqrt{ }$ & $\sqrt{ }$ & $\sqrt{ }$ \\
\hline $\begin{array}{l}\text { ADA } 40 \mathrm{mg} \\
\text { every } 2 \text { weeks }\end{array}$ & 208 & $41.7 \pm 11.69$ & $157(75.5)$ & $11.3 \pm 9.99$ & & & & & & & & & \\
\hline Placebo & 107 & $43.4 \pm 11.32$ & 79 (73.8) & $10.0 \pm 8.34$ & & & & & & & & & \\
\hline \multicolumn{14}{|l|}{ ETA } \\
\hline $\begin{array}{l}\text { Brandt J. } 2003 \\
\text { [32] }\end{array}$ & 30 & & & & 24 & NSAIDs & 8 & $\sqrt{ }$ & $\sqrt{ }$ & $\sqrt{ }$ & $\sqrt{ }$ & $\sqrt{ }$ & $\sqrt{ }$ \\
\hline $\begin{array}{l}\text { ETA } 25 \mathrm{mg} \\
\text { twice weekly }\end{array}$ & 14 & $38.9 \pm 9.1$ & $10(71.4)$ & $14.9 \pm 8.3$ & & & & & & & & & \\
\hline Placebo & 16 & $32.0 \pm 7.5$ & $12(75)$ & $11.4 \pm 8.8$ & & & & & & & & & \\
\hline $\begin{array}{l}\text { Davis JC Jr. } \\
2003 \text { [33] }\end{array}$ & 277 & & & & 24 & $\begin{array}{l}\text { DMARDs, NSAIDs and } \\
\text { glucocorticoids }\end{array}$ & 6 & $?$ & $?$ & $\sqrt{ }$ & $\sqrt{ }$ & $\sqrt{ }$ & $\sqrt{ }$ \\
\hline $\begin{array}{l}\text { ETA } 25 \mathrm{mg} \\
\text { twice weekly }\end{array}$ & 138 & $42.1(24-70)$ & 105 (76) & $10.1(0-30.7)$ & & & & & & & & & \\
\hline Placebo & 139 & $41.9(18-65)$ & 105 (76) & $10.5(0-35.3)$ & & & & & & & & & \\
\hline $\begin{array}{l}\text { van der Heijde D. } \\
2006 \text { [34] }\end{array}$ & 356 & & & & 12 & $\begin{array}{l}\text { DMARDs, NSAIDs and } \\
\text { glucocorticoids }\end{array}$ & 6 & $?$ & $?$ & $\sqrt{ }$ & $\sqrt{ }$ & $\sqrt{ }$ & $\sqrt{ }$ \\
\hline $\begin{array}{l}\text { ETA } 25 \mathrm{mg} \\
\text { twice weekly }\end{array}$ & 150 & $39.8 \pm 10.7$ & 114 (76) & $10.0 \pm 9.1$ & & & & & & & & & \\
\hline $\begin{array}{l}\text { ETA } 50 \text { mg } \\
\text { weekly }\end{array}$ & 155 & $41.5 \pm 11.0$ & 109 (70) & $9.0 \pm 8.7$ & & & & & & & & & \\
\hline Placebo & 51 & $40.1 \pm 10.9$ & $40(78)$ & $8.5 \pm 6.8$ & & & & & & & & & \\
\hline \multicolumn{14}{|l|}{ IFX } \\
\hline $\begin{array}{l}\text { Braun J. } \\
2002[35]\end{array}$ & 69 & & & & 12 & NSAIDs & 8 & $\sqrt{ }$ & $\sqrt{ }$ & $\sqrt{ }$ & $\sqrt{ }$ & $\sqrt{ }$ & $\sqrt{ }$ \\
\hline IFX 5 mg/Kg & 34 & $40.6 \pm 8.0$ & $23(68)$ & $16.4 \pm 8.3$ & & & & & & & & & \\
\hline Placebo & 35 & $39.0 \pm 9.1$ & $22(63)$ & $14.9 \pm 9.3$ & & & & & & & & & \\
\hline $\begin{array}{l}\text { Marzo-Ortega H. } \\
2005 \text { [36] }\end{array}$ & 42 & & & & 30 & NSAIDs, oral corticosteroids & 8 & $\sqrt{ }$ & $\sqrt{ }$ & $\sqrt{ }$ & $\sqrt{ }$ & $\sqrt{ }$ & $\sqrt{ }$ \\
\hline $\begin{array}{l}\text { IFX } 5 \mathrm{mg} / \\
\mathrm{Kg}+\mathrm{MTX}\end{array}$ & 28 & $41(28-74)$ & $23(82.14)$ & $8(0-41)$ & & & & & & & & & \\
\hline Placebo + MTX & 14 & $39(30-56)$ & $11(78.57)$ & $10(0-35)$ & & & & & & & & & \\
\hline
\end{tabular}


Table 1 Basic characteristics of included studies (Continued)

\begin{tabular}{|c|c|c|c|c|c|c|c|c|c|c|c|c|c|}
\hline \multicolumn{14}{|l|}{$\overline{\mathrm{GOL}}$} \\
\hline $\begin{array}{l}\text { Inman RD. } \\
2008[37]\end{array}$ & 356 & & & & 24 & $\begin{array}{l}\text { NSAIDs, MTX, SSA, HCQ, } \\
\text { corticosteroids }\end{array}$ & 7 & $?$ & $?$ & $\sqrt{ }$ & $\sqrt{ }$ & $\sqrt{ }$ & $\sqrt{ }$ \\
\hline GOL 50 mg & 138 & $38(29-46)$ & $102(73.8)$ & $5.15(1.60-11.60)$ & & & & & & & & & \\
\hline GOL 100 mg & 140 & $38(30-47)$ & $98(70.0)$ & $5.20(1.50-13.25)$ & & & & & & & & & \\
\hline Placebo & 78 & $41(31-50)$ & $55(70.5)$ & $7.25(2.80-18.60)$ & & & & & & & & & \\
\hline \multicolumn{14}{|l|}{ CZP } \\
\hline $\begin{array}{l}\text { Landewé R. } \\
2014 \text { [38] }\end{array}$ & 325 & & & & 24 & DMARDs, NSAIDs, MTX, SSA & 6 & $?$ & $?$ & $\sqrt{ }$ & $\sqrt{ }$ & $\sqrt{ }$ & $\sqrt{ }$ \\
\hline $\begin{array}{l}\text { CZP } 200 \text { mg } \\
\text { every } 2 \text { weeks }\end{array}$ & 111 & $39.1 \pm 11.9$ & $67(60.4)$ & $6.9(0.3-34.2)$ & & & & & & & & & \\
\hline $\begin{array}{l}\text { CZP } 400 \text { mg } \\
\text { every } 4 \text { weeks }\end{array}$ & 107 & $39.8 \pm 11.3$ & $68(63.6)$ & $7.9(0.3-44.8)$ & & & & & & & & & \\
\hline Placebo & 107 & $39.9 \pm 12.4$ & $65(60.7)$ & $7.7(0.3-50.9)$ & & & & & & & & & \\
\hline
\end{tabular}

$\mathrm{ADA}=$ adalimumab; $\mathrm{ETA}=$ etanercept; IFX = infliximab; GOL = golimumab; CZP: certolizumab; MTX = methotrexate; DMARDs = disease-modifying antirheumatic drugs; NSAIDs = non-steroidal anti-inflammatory drugs; $\mathrm{SSA}=$ sulfasalazine; $\mathrm{HCQ}=$ hydroxychloroquine; $\sqrt{ }$, low risk of bias; ?, unclear risk of bias. 


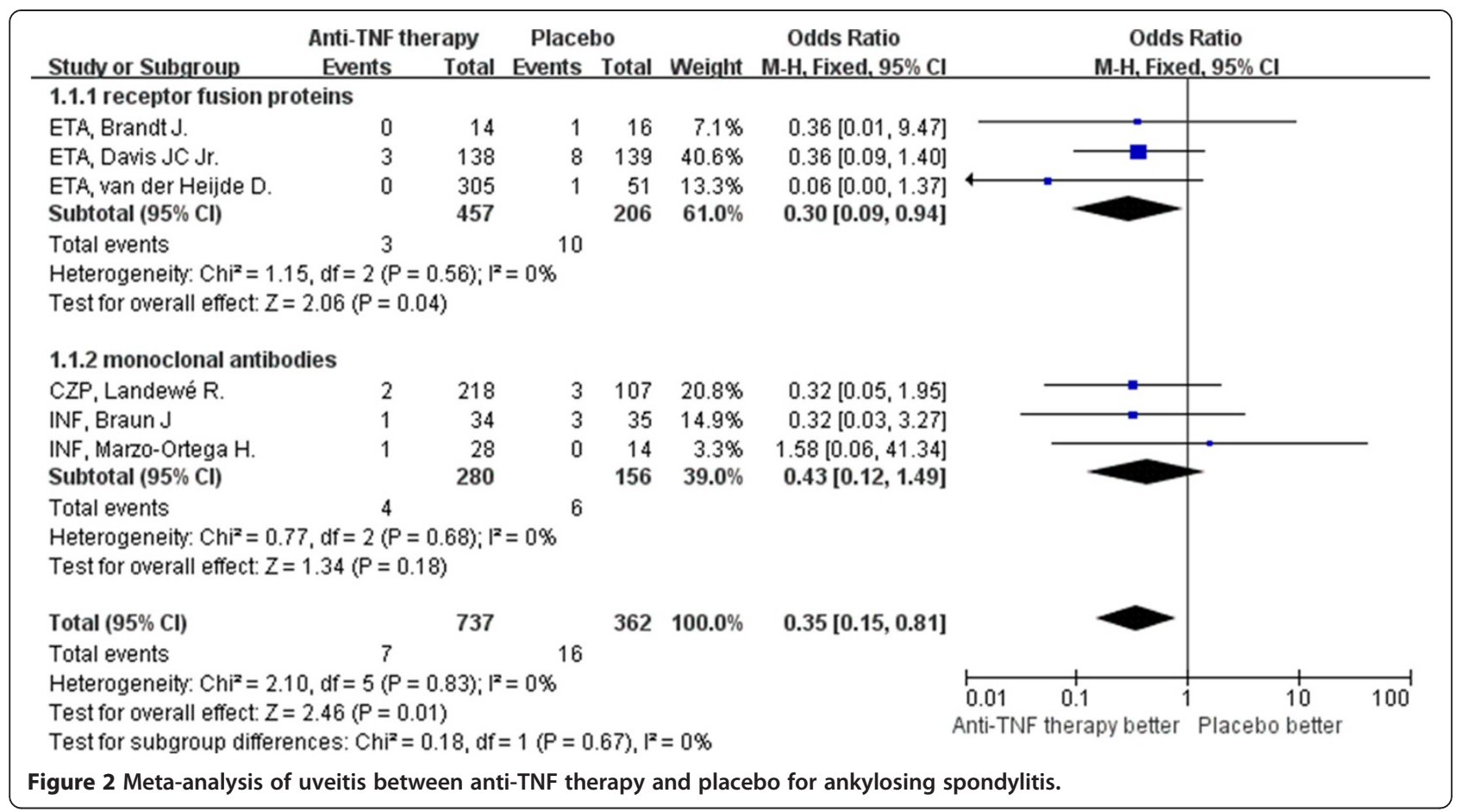

monoclonal anti-TNF antibodies were not. Neither monoclonal antibodies nor receptor fusion proteins significantly differed from placebo in treating IBD.

Anti-TNF therapy has been shown to be beneficial for the treatment of uveitis in patients with AS. A retrospective study [39] of patients with spondyloarthropathy further confirms the efficacy of anti-TNF therapy in reducing acute uveitis flares. Therefore, all available data imply that ETA would not be as effective as monoclonal anti-TNF antibodies [40-42]. However, our results differed. This discrepancy may reflect the biggest difference between our study and previous ones; we included trials

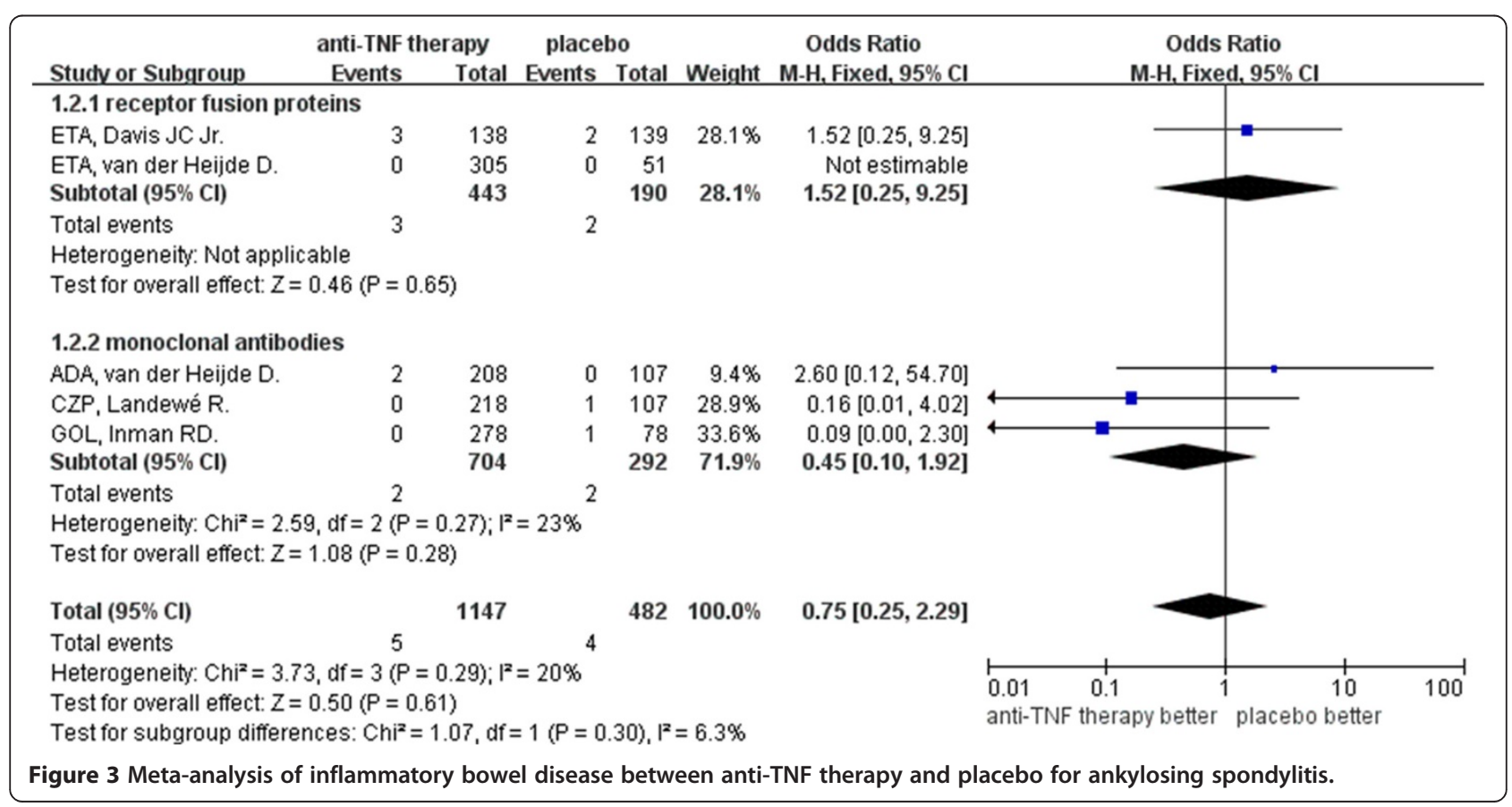




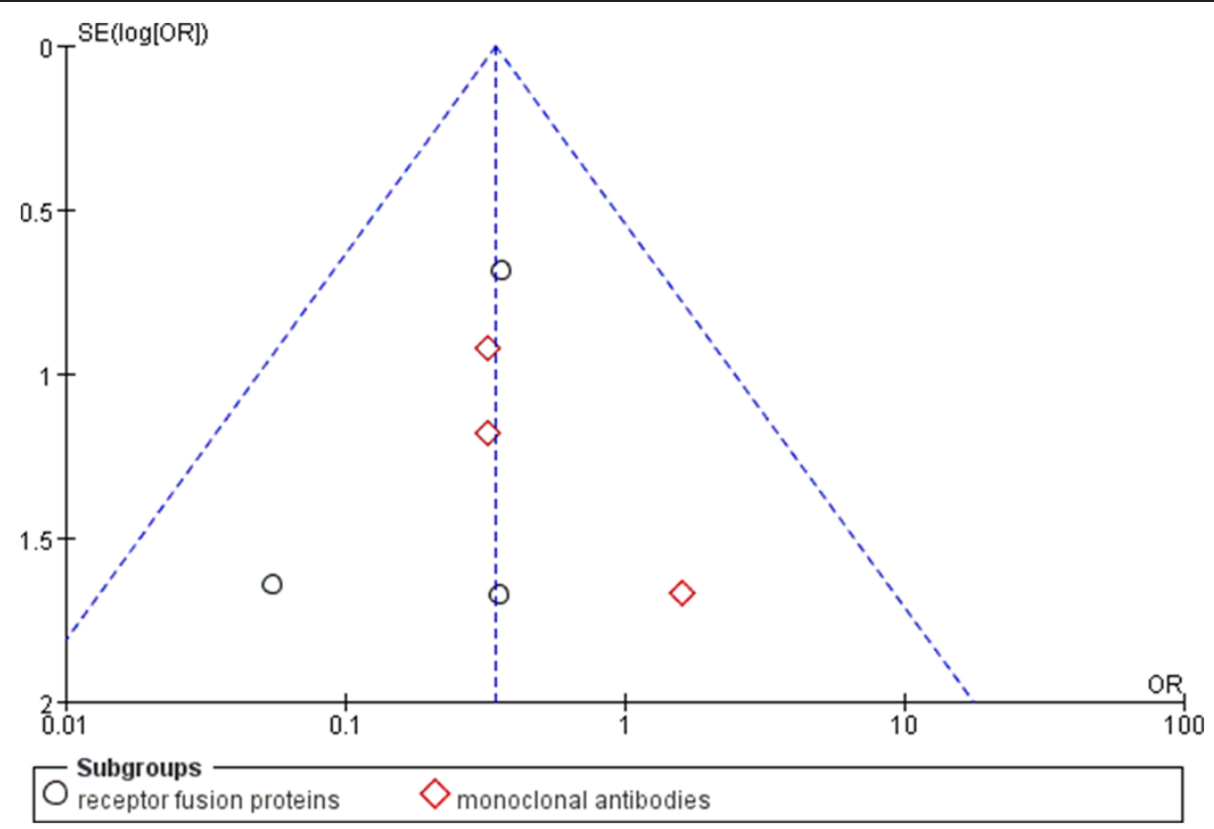

Figure 4 Funnel plot of included trials that reported uveitis.

that were all prospective RCTs whereas previous studies were almost all retrospective which tend to show larger risk values. Moreover, the mechanisms of anti-TNF antibodies and receptor fusion proteins are different; besides TNF- $\alpha$, ETA also inhibits TNF- $\beta$. In an animal model of uveitis, higher TNF- $\beta$ levels were found; ETA would therefore be expected to be even more effective [43]. More RCTs are required to further define the effect of ETA in AS patients with uveitis.

Braun et al. [44] investigated flare-ups or new-onset IBD in patients with AS who were treated with INF, ETA and ADA. New-onset and flares of IBD are infrequent in

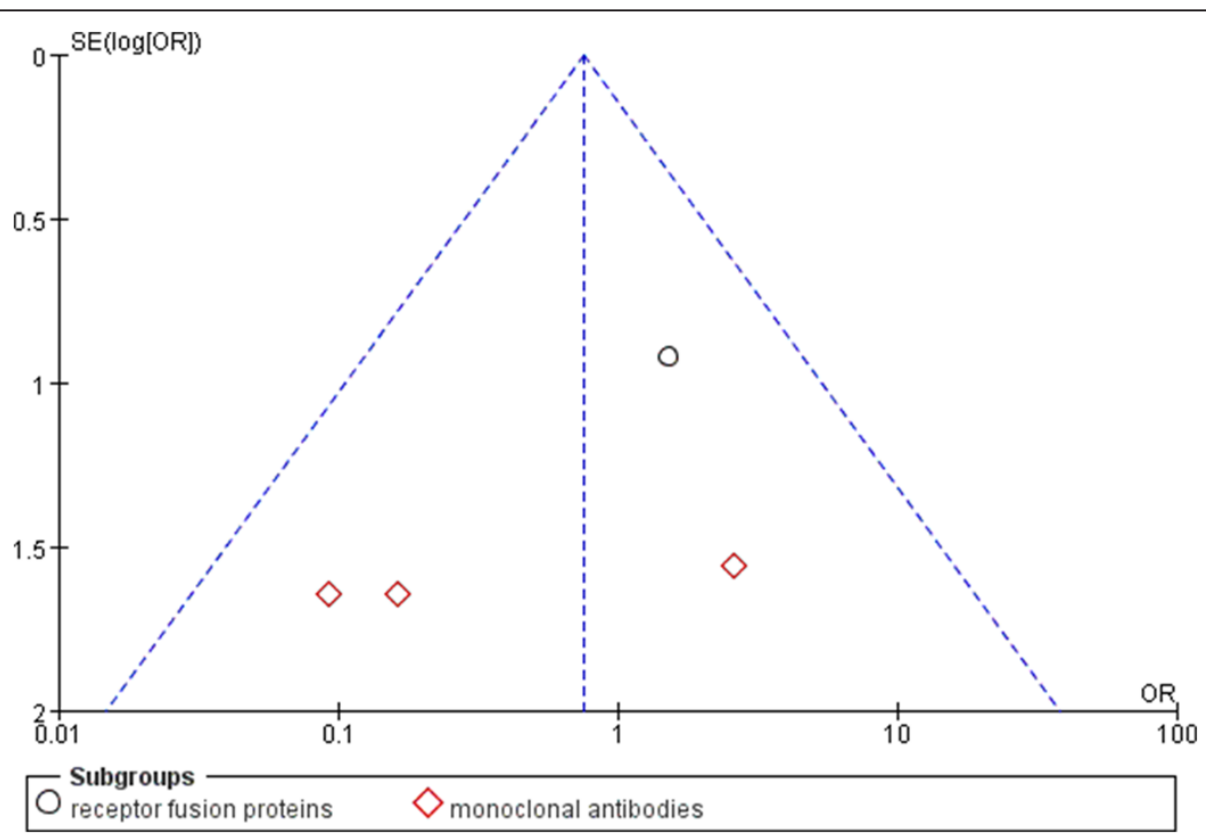

Figure 5 Funnel plot of included trials that reported inflammatory bowel diseases. 
AS patients who receive anti-TNF therapy. The results showed that only INF and ADA might prevent IBD activity, both of which were associated with significant IBD rate reductions compared with ETA. The incidence of new-onset IBD in patients treated with placebo was not statistically different from that for any anti-TNF agent. ETA is not effective in controlling active CD [45]; in fact, cases have been reported of possible associated CD flareups [46] or new-onset CD [47] in AS patients undergoing ETA therapy. In our meta-analysis, we found that neither monoclonal anti-TNF antibodies nor TNF receptor fusion proteins were efficacious for IBD, but monoclonal antiTNF antibodies had lower OR (implying greater efficacy) than TNF receptor fusion proteins. Only 5 small RCTs in our analysis had AS patients with IBD who were treated with anti-TNF agents. More RCT data is needed to establish the efficacy of anti-TNF antibodies for IBD in these patients.

Although anti-TNF agents are effective in treating skin and nail lesions of psoriasis $[48,49]$, treatment with antiTNF agents also can result in new manifestations of psoriasis for some patients [50]. We were unable to assess this in our meta-analysis because the included trails had no reported data of psoriasis.

The present study evaluated the efficacy of anti-TNF therapy on the frequency of EAMs in patients with AS. Anti-TNF therapy including ETA could be a credible alternative for AS patients who have uveitis. However, no anti-TNF therapy was efficacious for treating IBD in patients with AS. The 8 included studies that met the inclusion criteria had high-moderate Jadad scores; therefore the conclusions of this systematic analysis are reliable. More high-quality, large prospective RCTs with long-term follow-up are needed to confirm the efficacy and outcomes of anti-TNF therapy for EAMs of AS.

\section{Conclusions}

Compared with placebo, anti-TNF therapy including ETA was associated with significantly fewer flares and new onset of uveitis, but were not significant efficacious for treating IBD in AS patients. This meta-analysis of patient-level data from 8 RCTs significantly advances the notion that anti-TNF therapy may be a credible alternative for AS patients with uveitis. Future studies involving anti-TNF therapy for EAMs of AS are needed.

\footnotetext{
Abbreviations

TNF: Anti-tumor necrosis factor; AS: Ankylosing spondylitis; EAM: Extra-articular manifestation; RCT: Randomized controlled trial; IBD: Inflammatory bowel disease; CD: Crohn's disease; UC: Ulcerative colitis; ASAS: Assessments in Ankylosing Spondylitis International Society; EULAR: European League against Rheumatism; NSAIDs: Non-steroidal anti-inflammatory drugs; DMARDs: Diseasemodifying antirheumatic drugs; INF: Infliximab; IgG: Immunoglobulin G; ADA: Adalimumab; GOL: Golimumab; CZP: Certolizumab; ETA: Etanercept; OR: Odds ratio; Cl: Confidence interval; HLA: Human leukocyte antigen.
}

\section{Competing interests}

The authors declare that they have no competing interests.

\section{Authors' contributions}

DW and NZ conceived and designed the study. DW, LXH and TJ analyzed and interpreted the data. YYG, NNX and SZ contributed to acquisition of data. All authors helped draft the manuscript and its revisions for critically important intellectual content, and gave final approval of the version to be published.

\section{Acknowledgements}

We thank Marla Brunker who provided professional English editing service.

\section{Author details}

${ }^{1}$ Second Departments of Rheumatology, Shengjing Hospital of China Medical University, 39, Huaxiang Road, Tiexi District, Shenyang 110022, Liaoning, China. 'First Departments of Rheumatology, Shengjing Hospital of China Medical University, 39, Huaxiang Road, Tiexi District, Shenyang 110022Liaoning, China.

Received: 15 October 2014 Revised: 18 October 2014

Accepted: 30 January 2015

Published online: 10 February 2015

\section{References}

1. Sieper J, Rudwaleit M, Khan MA, Braun J. Concepts and epidemiology of spondyloarthritis. Best Pract Res Clin Rheumatol. 2006;20:401-17.

2. Lee JH, Jun JB, Jung S, Bae SC, Yoo DH, Kim TY, et al. Higher prevalence of peripheral arthritis among ankylosing spondylitis patients. J Korean Med Sci. 2002;17:669-73.

3. Vander Cruyssen B, Ribbens C, Boonen A, Mielants H, de Vlam K, Lenaerts J, et al. The epidemiology of ankylosing spondylitis and the commencement of anti-TNF therapy in daily rheumatology practice. Ann Rheum Dis. 2007;66:1072-7.

4. Elewaut D, Matucci-Cerinic M. Treatment of ankylosing spondylitis and extra-articular manifestations in everyday rheumatology practice. Rheumatology (Oxford). 2009;48:1029-35.

5. Hajj-Ali RA, Lowder C, Mandell BF. Uveitis in the internist's office: are a patient's eye symptoms serious? Cleve Clin J Med. 2005;72:329-39.

6. Rosembaum JT. Acute uveitis and spondyloarthropathies. Rheum Dis Clin North Am. 1992;18:143-51.

7. Stolwijk C, van Tubergen A, Castillo-Ortiz JD, Boonen A. Prevalence of extraarticular manifestations in patients with ankylosing spondylitis: a systematic review and meta-analysis. Ann Rheum Dis. 2015;74:65-73.

8. Muñoz-Fernández S, Hidalgo V, Fernández-Melón J, Schlincker A, Bonilla G, Ruiz-Sancho D, et al. Sulfasalazine reduces the number of flares of acute anterior uveitis over a one-year period. J Rheumatol. 2003;30:1277-9.

9. Simonini G, Paudyal P, Jones GT, Cimaz R, Macfarlane GJ. Current evidence of methotrexate efficacy in childhood chronic uveitis: a systematic review and meta-analysis approach. Rheumatology (Oxford). 2013;52:825-31.

10. Pérez-Guijo V, Santos-Lacomba M, Sánchez-Hernández M, Castro-Villegas Mdel C, Gallardo-Galera JM, Collantes-Estévez E. Tumour necrosis factoralpha levels in aqueous humour and serum from patients with uveitis: the involvement of HLA-B27. Curr Med Res Opin. 2004;20:155-7.

11. Rudwaleit M, Rødevand E, Holck P, Vanhoof J, Kron M, Kary S, et al. Adalimumab effectively reduces the rate of anterior uveitis flares in patients with active ankylosing spondylitis: results of a prospective open-label study. Ann Rheum Dis. 2009:68:696-701.

12. Braun J, Baraliakos X, Listing J, Sieper J. Decreased incidence of anterior uveitis in patients with ankylosing spondylitis treated with the anti-tumor necrosis factor agents infliximab and etanercept. Arthritis Rheum. 2005;52:2447-51.

13. Mowat C, Cole A, Windsor A, Ahmad T, Arnott I, Driscoll R, et al. Guidelines for the management of inflammatory bowel disease in adults. Gut. 2011;60:571-607.

14. Williams C, Panaccione R, Ghosh S, Rioux K. Optimizing clinical use of mesalazine (5-aminosalicylic acid) in inflammatory bowel disease. Therap Adv Gastroenterol. 2011;4:237-48.

15. Braun J, Baraliakos X, Listing J, Davis J, van der Heijde D, Haibel H, et al. Differences in the incidence of flares or new onset of inflammatory bowel 
diseases in patients with ankylosing spondylitis exposed to therapy with anti-tumor necrosis factor alpha agents. Arthritis Rheum. 2007;57:639-47.

16. Braun J, van den Berg R, Baraliakos X, Boehm H, Burgos-Vargas R, CollantesEstevez $E$, et al. 2010 update of the ASAS/EULAR recommendations for the management of ankylosing spondylitis. Ann Rheum Dis. 2011;70:896-904.

17. Feldmann M, Elliott MJ, Woody JN, Maini RN. Anti-tumor necrosis factoralpha therapy of rheumatoid arthritis. Adv Immunol. 1997;64:283-350.

18. Nash PT, Florin TH. Tumour necrosis factor inhibitors. Med J Aust. 2005;183:205-8.

19. Deeks ED. Certolizumab pegol: a review of its use in the management of rheumatoid arthritis. Drugs. 2013;73:75-97.

20. Moreland LW, Baumgartner SW, Schiff MH, Tindall EA, Fleischmann RM Weaver $\mathrm{AL}$, et al. Treatment of rheumatoid arthritis with a recombinant human tumor necrosis factor receptor(p75)-Fc fusion protein. N Engl J Med. 1997;337:141-7.

21. Giardina AR, Ferrante A, Ciccia F, Impastato R, Miceli MC, Principato A, et al A 2-year comparative open label randomized study of efficacy and safety of etanercept and infliximab in patients with ankylosing spondylitis. Rheumatol Int. 2010;30:1437-40

22. Braun J, Baraliakos $X$, Hermann KG, van der Heijde D, Inman RD, Deodhar $\mathrm{AA}$, et al. Golimumab reduces spinal inflammation in ankylosing spondylitis: MRI results of the randomised, placebo- controlled GO-RAISE study. Ann Rheum Dis. 2012;71:878-84

23. Baraliakos X, Listing J, Fritz C, Haibel H, Alten R, Burmester GR, et al. Persistent clinical efficacy and safety of infliximab in ankylosing spondylitis after 8 years-early clinical response predicts long-term outcome. Rheumatology (Oxford). 2011;50:1690-9.

24. Braun J, van der Horst-Bruinsma IE, Huang F, Burgos-Vargas R, Vlahos B, Koenig AS, et al. Clinical efficacy and safety of etanercept versus sulfasalazine in patients with ankylosing spondylitis: a randomized, double-blind trial. Arthritis Rheum. 2011;63:1543-51.

25. Sieper J, van der Heijde D, Dougados M, Brown LS, Lavie F, Pangan AL. Early response to adalimumab predicts long-term remission through 5 years of treatment in patients with ankylosing spondylitis. Ann Rheum Dis. 2012;71:700-6

26. Machado MA, Barbosa MM, Almeida AM, de Araújo VE, Kakehasi AM Andrade El, et al. Treatment of ankylosing spondylitis with TNF blockers: a meta-analysis. Rheumatol Int. 2013;33:2199-213.

27. Oremus M, Wolfson C, Perrault A, Demers L, Momoli F, Moride Y. Interrater reliability of the modified Jadad quality scale for systematic reviews of Alzheimer's disease drug trials. Dement Geriatr Cogn Disord. 2001;12:232-6.

28. Higgins JP, Altman DG, Gøtzsche PC, Jüni P, Moher D, Oxman AD, et al. The Cochrane Collaboration's tool for assessing risk of bias in randomised trials. BMJ. 2011;343:d5928.

29. Cochrane handbook for systematic reviews of interventions version 5.1.0 (updated March 2011). [http://handbook.cochrane.org/]

30. Higgins JP, Thompson SG. Quantifying heterogeneity in a meta-analysis. Stat Med. 2002;21:1539-58.

31. van der Heijde D, Kivitz A, Schiff MH, Sieper J, Dijkmans BA, Braun J, et al. Efficacy and safety of adalimumab in patients with ankylosing spondylitis: results of a multicenter, randomized, double-blind, placebo-controlled trial. Arthritis Rheum. 2006;54:2136-46.

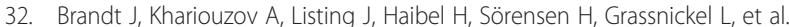
Six-month results of a double-blind, placebo-controlled trial of etanercept treatment in patients with active ankylosing spondylitis. Arthritis Rheum. 2003;48:1667-75

33. Davis Jr JC, Van Der Heijde D, Braun J, Dougados M, Cush J, Clegg DO, et al. Recombinant human tumor necrosis factor receptor (etanercept) for treating ankylosing spondylitis: a randomized, controlled trial. Arthritis Rheum. 2003:48:3230-6.

34. van der Heijde D, Da Silva JC, Dougados M, Geher P, van der HorstBruinsma I, Juanola $X$, et al. Etanercept 50 mg once weekly is as effective as $25 \mathrm{mg}$ twice weekly in patients with ankylosing spondylitis. Ann Rheum Dis. 2006;65:1572-7.

35. Braun J, Brandt J, Listing J, Zink A, Alten R, Golder W, et al. Treatment of active ankylosing spondylitis with infliximab: a randomised controlled multicentre trial. Lancet. 2002;359:1187-93.

36. Marzo-Ortega H, McGonagle D, Jarrett $\mathrm{S}$, Haugeberg G, Hensor E, O'connor $P$, et al. Infliximab in combination with methotrexate in active ankylosing spondylitis: a clinical and imaging study. Ann Rheum Dis. 2005;64:1568-75.
37. Inman RD, Davis Jr JC, Heijde D, Diekman L, Sieper J, Kim SI, et al. Efficacy and safety of golimumab in patients with ankylosing spondylitis: results of a randomized, double-blind, placebo-controlled, phase III trial. Arthritis Rheum. 2008:58:3402-12.

38. Landewé R, Braun J, Deodhar A, Dougados M, Maksymowych WP, Mease PJ, et al. Efficacy of certolizumab pegol on signs and symptoms of axial spondyloarthritis including ankylosing spondylitis: 24-week results of a double-blind randomised placebo-controlled Phase 3 study. Ann Rheum Dis. 2014;73:39-47

39. Guignard S, Gossec L, Salliot C, Ruyssen-Witrand A, Luc M, Duclos M, et al. Efficacy of tumour necrosis factor blockers in reducing uveitis flares in patients with spondyloarthropathy: a retrospective study. Ann Rheum Dis. 2006;65:1631-4.

40. Pato E, Muñoz-Fernández S, Francisco F, Abad MA, Maese J, Ortiz A, et al. Systematic review on the effectiveness of immunosuppressants and biological therapies in the treatment of autoimmune posterior uveitis. Semin Arthritis Rheum. 2011:40:314-23.

41. D'Angelo S, Palazzi C, Cantini F, Lubrano E, Marchesoni A, Mathieu A, et al. Etanercept in spondyloarthopathies. Part II: safety and pharmacoeconomic issues. Clin Exp Rheumatol. 2011;29:865-70.

42. Wendling D, Paccou J, Berthelot JM, Flipo RM, Guillaume-Czitrom S, Prati C, et al. New onset of uveitis during anti-tumor necrosis factor treatment for rheumatic diseases. Semin Arthritis Rheum. 2011;41:503-10.

43. Savion S, Oddo S, Grover S, Caspi RR. Uveitogenic T lymphocytes in the rat: pathogenicity vs. lymphokine production, adhesion molecules and surface antigen expression. J Neuroimmunol. 1994;55:35-44.

44. Braun J, Baraliakos X, Listing J, Davis J, van der Heijde D, Haibel H, et al. Differences in the incidence of flares or new onset of inflammatory bowel diseases in patients with ankylosing spondylitis exposed to therapy with anti-tumor necrosis factor alpha agents. Arthritis Rheum. 2007;57:639-47.

45. Sandborn WJ, Hanauer SB, Katz S, Safdi M, Wolf DG, Baerg RD, et al. Etanercept for active Crohn's disease: a randomized, double-blind, placebocontrolled trial. Gastroenterology. 2001;121:1088-94.

46. Marzo-Ortega H, McGonagle D, O'Connor P, Emery P. Efficacy of etanercept for treatment of Crohn's related spondyloarthritis but not colitis. Ann Rheum Dis. 2003;62:74-6.

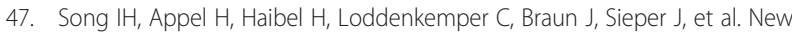
onset of Crohn's disease during treatment of active ankylosing spondylitis with etanercept. J Rheumatol. 2008;35:532-6.

48. Kyriakou A, Patsatsi A, Sotiriadis D. Anti-TNF agents and nail psoriasis: a single-center, retrospective, comparative study. J Dermatolog Treat. 2013:24:162-8.

49. Leonardi CL, Powers JL, Matheson RT, Goffe BS, Zitnik R, Wang A, et al. Etanercept Psoriasis Study Group. Etanercept as monotherapy in patients with psoriasis. N Engl J Med. 2003;349:2014-22.

50. Grinblat B, Scheinberg M. The enigmatic development of psoriasis and psoriasiform lesions during anti-TNF therapy: a review. Semin Arthritis Rheum. 2008:37:251-5.

\section{Submit your next manuscript to BioMed Central and take full advantage of:}

- Convenient online submission

- Thorough peer review

- No space constraints or color figure charges

- Immediate publication on acceptance

- Inclusion in PubMed, CAS, Scopus and Google Scholar

- Research which is freely available for redistribution 